\title{
American College of Cardiology/American Heart Association 2016 dual antiplatelet therapy (DAPT) focused update: Implications for surgeons
}

\author{
Richard J. Shemin, MD
}

\footnotetext{
From the Division of Cardiothoracic Surgery, Department of Surgery, Ronald Reagan UCLA Medical Center, David Geffen School of Medicine at UCLA, Los Angeles, Calif.

Disclosures: Author has nothing to disclose with regard to commercial support.

Received for publication April 13, 2016; accepted for publication April 13, 2016; available ahead of print May 14, 2016.

Address for reprints: Richard J. Shemin, MD, 100 UCLA Medical Plaza, Suite 730, Los Angeles, CA 90095 (E-mail: Rshemin@mednet.ucla.edu).

J Thorac Cardiovasc Surg 2016;152:1276-8 $0022-5223 / \$ 36.00$

Copyright $(c) 2016$ by The American Association for Thoracic Surgery http://dx.doi.org/10.1016/j.jtcvs.2016.04.047
}

Patients with acute coronary syndrome (ACS), myocardial infarction (STEMI), percutaneous coronary intervention (PCI), stable ischemic heart disease (SIHD), and non-STelevation acute coronary syndrome (NSTE-ACS) are often treated with dual antiplatelet therapy (DAPT). The guidelines for the duration of DAPT therapy, specific drugs, and dosing are aimed at reducing ischemic risk and minimizing bleeding episodes. ${ }^{1-7}$

DAPT has significant implications for cardiac surgeons caring for these patients. Several clinical scenarios are common. Should DAPT be stopped preoperatively to minimize postoperative bleeding complications? When should DAPT be restarted postoperatively? Finally, what is the role of DAPT after coronary bypass grafting (CABG) when the patient was not receiving these medications preoperatively?

The 2016 American College of Cardiology (ACC)/ American Heart Association (AHA) focused DAPT update is based on the results of numerous recent studies on the duration of therapy, mono versus dual therapy, and specific indications for DAPT. ${ }^{8-21}$ The dual combination is primarily aspirin $(81 \mathrm{mg})$ and a $\mathrm{P} 2 \mathrm{Y}_{12}$ receptor inhibitor (clopidogrel, prasugrel, or ticagrelor).

The update replaces recommendations made in 6 previous versions of the guidelines and includes recommendations for DAPT after CABG. ${ }^{1-7}$ Six guideline working groups determined the class of recommendation (COR) and level of evidence (LOE) for each recommendation using the 2015 ACC/AHA COR/LOE system. ${ }^{1,7,8}$

The basic principles are as follows:

- Intensity of therapy is a risk/benefit ratio of decreasing ischemic risk and increasing bleeding risk.

- Shorter duration of DAPT can be considered for patients at lower ischemic risk with a higher bleeding risk.

- Indications for DAPT are similar for NSTE-MI, ACS and STEMI (ie, all part of the ACS spectrum).

- DAPT is a COR:I recommendation ("should be given") for therapy in most clinical settings for at least 6 to 12 months

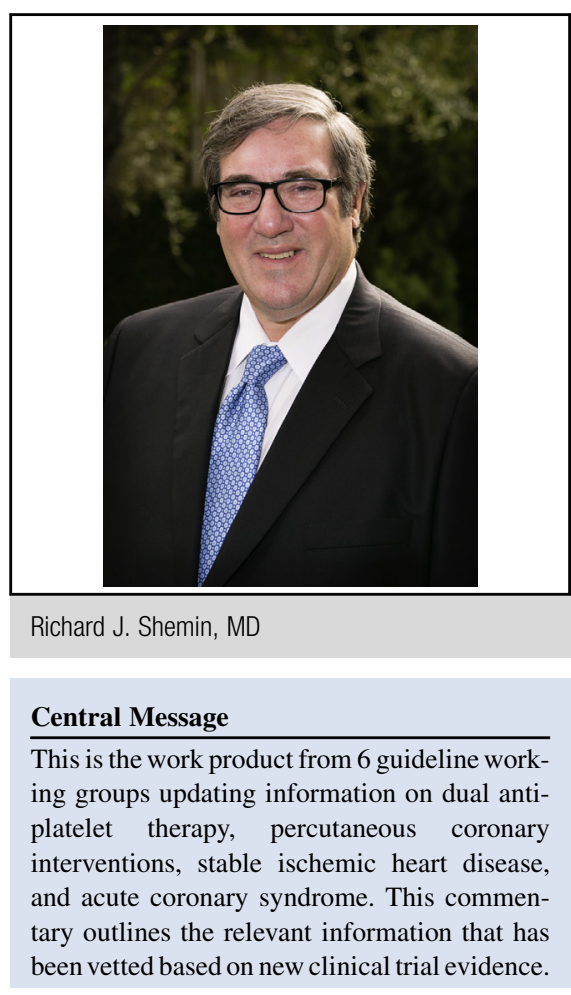

See Article page 1243 .

and a COR: IIB recommendation ("may be reasonable") for therapy beyond 6 to 12 months. Duration of prolonged therapy and true optimal duration are unknown.

- Aspirin therapy almost always should be continued indefinitely in patients with CAD. Lower aspirin doses decrease the risk of bleeding complications with comparable ischemic protection. COR: I; LOE: B-NR.

The following factors are considered when evaluating the risk of bleeding: $\mathrm{CHA}_{2} \mathrm{DS}_{2}$-VASc (congestive heart failure, hypertension, age, diabetes mellitus, prior stroke or transient ischemic attack or thromboembolism) and HAS-BLED (hypertension, abnormal renal and liver function, stroke, bleeding, labile international normalized ratios, elderly, drugs or alcohol) scores.

- The use of triple therapy (ie, DAPT and coumadin). This should be used for as short a time as possible, with a target international normalized ratio of 2.0 to 2.5 . 
- Aspirin dose. Low-dose aspirin reduces bleeding risk and is as effective as higher doses.

- Clopidogrel as the P2Y $\mathrm{Y}_{12}$ inhibitor of choice.

- A proton pump inhibitor should be considered in patients at risk for gastrointestinal bleeding.

\section{CABG RECOMMENDATIONS}

The use of ASA treatment to improve 1-year vein graft patency and to reduce major adverse cardiovascular events has been a standard of practice since the work of Chesebro and colleagues published in $1984 .^{22}$ The postoperative use of DAPT in patients with a previously placed patent stent is a common clinical practice. The decision when to discontinue aspirin and/or $\mathrm{P}_{2} \mathrm{Y}_{12}$ inhibitor before elective CABG surgery is a clinical judgment based on the risks of ischemia versus postoperative bleeding. ${ }^{23,24}$

The evidence-based recommendations for the postoperative use of DAPT in patients not taking these drugs preoperatively are not clear based on the literature. The impact of clopidogrel on graft occlusion after on-pump CABG in both randomized and nonrandomized studies has failed to demonstrate a benefit for DAPT over treatment with aspirin alone up to 1 year of follow-up. One randomized controlled trial did show better graft patency with DAPT compared with aspirin monotherapy at 3 months. A meta-analysis from 5 randomized controlled trials have reported mixed results as well. The patients who received DAPT clearly experienced more major bleeding, with no improvement in arterial graft patency. ${ }^{23,25-32}$ DAPT may have its major impact on improved vein graft patency and clinical outcomes in off-pump CABG surgery.

Thus, the recommendations are summarized as follows:

1. In patients undergoing $\mathrm{CABG}$ after coronary stent implantation, $\mathrm{P}^{2} \mathrm{Y}_{12}$ inhibitor therapy should be resumed for the recommended duration of DAPT. COR: I; LOE: C-EO (consensus expert opinion).

2. In patients with ACS (NSTEMI, ACS, or STEMI) receiving DAPT before CABG, DAPT should be continued to the completion of 12 months of therapy. COR: I; LOE: C-LD (limited data).

3. Aspirin $81 \mathrm{mg} /$ day is recommended in all patients with CABG. COR: I; LOE: B-NR (nonrandomized).

4. In patients undergoing CABG for SIHD, DAPT with aspirin and clopidogrel for 12 months may be reasonable to improve graft patency. COR: IIb; LOE: B-NR.

In conclusion, DAPT therapy continues to evolve in patients with coronary artery disease treated with surgery and/or PCI. The cardiac surgeon has the responsibility to continue preoperative therapy. The evidence for adding a $\mathrm{P}^{2} \mathrm{Y}_{12}$ inhibitor to aspirin in patients not receiving these drugs preoperatively will continue to evolve as future trials aim to provide the best evidence to help reduce ischemic events and bleeding risks.

\section{References}

1. Levine GN, Bates ER, Blankenship JC, Bailey SR, Bittl JA, Cercek B, et al. 2011 ACCF/AHA/SCAI guideline for percutaneous coronary intervention: a report of the American College of Cardiology Foundation/American Heart Association Task Force on Practice Guidelines and the Society for Cardiovascular Angiography and Interventions. J Am Coll Cardiol. 2011;58:e44-122.

2. Hillis LD, Smith PK, Anderson JL, Bittl JA, Bridges CR, Byrne JG, et al. 2011 ACCF/AHA guideline for coronary artery bypass graft surgery: a report of the American College of Cardiology Foundation/American Heart Association Task Force on Practice Guidelines. Developed in collaboration with The American Association for Thoracic Surgery, Society of Cardiovascular Anesthesiologists, and Society of Thoracic Surgeons. J Am Coll Cardiol. 2011;58:e123-210.

3. Fihn SD, Blankenship JC, Alexander KP, Bittl JA, Byrne JG, Fletcher BJ, et al 2014 ACC/AHA/AATS/PCNA/SCAI/STS focused update of the guideline for the diagnosis and management of patients with stable ischemic heart disease: a report of the American College of Cardiology/American Heart Association Task Force on Practice Guidelines, and The American Association for Thoracic Surgery, Preventive Cardiovascular Nurses Association, Society for Cardiovascular Angiography and Interventions, and Society of Thoracic Surgeons. J Am Coll Cardiol. 2015;64:1929-49.

4. Fihn SD, Gardin JM, Abrams J, Berra K, Blankenship JC, Dallas AP, et al. 2012 $\mathrm{CCF} / \mathrm{AHA} / \mathrm{ACP} / \mathrm{AATS} / \mathrm{PCNA} / \mathrm{SCAI} / \mathrm{STS}$ guideline for the diagnosis and management of patients with stable ischemic heart disease: a report of the American College of Cardiology Foundation/American Heart Association Task Force on Practice Guidelines and the American College of Physicians, American Association for Thoracic Surgery, Preventive Cardiovascular Nurses Association, Society for Cardiovascular Angiography and Interventions, and Society of Thoracic Surgeons. J Am Coll Cardiol. 2012;60:e44-164.

5. O'Gara PT, Kushner FG, Ascheim DD, Casey DE, Chung MK, de Lemos JA, et al. 2013 ACCF/AHA guideline for the management of ST-elevation myocardial infarction: a report of the American College of Cardiology Foundation/American Heart Association Task Force on Practice Guidelines. J Am Coll Cardiol. 2013;61:e78-140.

6. Amsterdam EA, Wenger NK, Brindis RG, Casey DE, Ganiats TG, Holmes DR, et al. 2014 AHA/ACC guideline for the management of patients with non-STelevation acute coronary syndromes: a report of the American College of Cardiology/American Heart Association Task Force on Practice Guidelines. J Am Coll Cardiol. 2014;64:e139-228.

7. Fleisher LA, Fleischmann KE, Auerbach AD, Barnaso SA, Beckman JA, Bozkurt B, et al. 2014 ACC/AHA guideline on perioperative cardiovascular evaluation and management of patients undergoing noncardiac surgery: a report of the American College of Cardiology/American Heart Association Task Force on Practice Guidelines. J Am Coll Cardiol. 2014;64:e77-137.

8. Colombo A, Chieffo A, Frasheri A, Garbo R, Massotti-Centol M, Salvatella N et al. Second-generation drug-eluting stent implantation followed by 6- versus 12-month dual antiplatelet therapy: the SECURITY randomized clinical trial. J Am Coll Cardiol. 2014;64:2086-397.

9. Feres F, Costa RA, Abizaid A, Leon MB, Marin-Neto JA, Botelho RV, et al. Three vs twelve months of dual antiplatelet therapy after zotarolimus-eluting stents: the OPTIMIZE randomized trial. JAMA. 2013;310:2510-22.

10. Gilard M, Barragan P, Noryani AA, Noor HA, Majwal T, Hovasse T, et al. Sixversus 24-month dual antiplatelet therapy after implantation of drug- eluting stents in patients nonresistant to aspirin: the randomized, multicenter ITALIC trial. J Am Coll Cardiol. 2015;65:777-86.

11. Gwon HC, Hahn JY, Park KW, Song YB, Chae IH, Lim DS, et al. Six-month versus 12-month dual antiplatelet therapy after implantation of drug-eluting stents: the Efficacy of Xience/Promus Versus Cypher to Reduce Late Loss After Stenting (EXCELLENT) randomized, multicenter study. Circulation. 2012;125: 505-13.

12. Helft G, Steg PG, Le FC, Le Feuvre C, Georges JL, Carrie D, et al. Stopping or continuing clopidogrel months after drug-eluting stent placement: the OPTIDUAL randomized trial. Eur Heart J. 2015;37:365-74.

13. Kim BK, Hong MK, Shin DH, Nam CM, Kim JS, Ko YG, et al. A new strategy for discontinuation of dual antiplatelet therapy: the RESET Trial (REal Safety and Efficacy of 3-month dual antiplatelet Therapy following Endeavor zotarolimus-eluting stent implantation). J Am Coll Cardiol. 2012;60:1340-8. 
14. Lee CW, Ahn JM, Park DW, Kang SJ, Lee SW, Kim YH, et al. Optimal duration of dual antiplatelet therapy after drug-eluting stent implantation: a randomized, controlled trial. Circulation. 2014;129:304-12.

15. Mauri L, Kereiakes DJ, Yeh RW, Driscoll-Shempp P, Cutlip DE, Steg G, et al. Twelve or 30 months of dual antiplatelet therapy after drug-eluting stents. N Engl J Med. 2014;371:2155-66.

16. Park SJ, Park DW, Kim YH, Kang SJ, Lee SW, Lee CW, et al. Duration of dual antiplatelet therapy after implantation of drug-eluting stents. N Engl J Med. 2010; 362:1374-82.

17. Schülz-Schüpke S, Byrne RA, ten Berg JM, Neumann FJ, Han Y, Adriaenssens T, et al. ISAR-SAFE: a randomized, double-blind, placebo-controlled trial of 6 versus 12 months of clopidogrel therapy after drug-eluting stenting. Eur Heart J. 2015;36:1252-63.

18. Valgimigli M, Campo G, Monti M, Vranckx P, Percoco G, Tumscitz C, et al. Short- versus long-term duration of dual-antiplatelet therapy after coronary stenting: a randomized multicenter trial. Circulation. 2012;125:2015-26.

19. Collet JP, Silvain J, Barthelemy O, Range G, Cayla G, Van Belle E, et al. Dualantiplatelet treatment beyond 1 year after drug-eluting stent implantation (ARCTIC-Interruption): a randomised trial. Lancet. 2014;384:1577-85.

20. Bonaca MP, Bhatt DL, Cohen M, Steg PG, Storey RF, Jensen EC, et al. Longterm use of ticagrelor in patients with prior myocardial infarction. $N$ Engl J Med. 2015;372:1791-800.

21. Roffi M, Patrono C, Collet JP, Mueller C, Valgimigli M, Andreotti F, et al. 2015 ESC guidelines for the management of acute coronary syndromes in patients presenting without persistent ST-segment elevation: Task Force for the Management of Acute Coronary Syndromes in Patients Presenting Without Persistent ST-Segment Elevation of the European Society of Cardiology (ESC). Eur Heart J. 2015;32:2999-3054.

22. Chesebro JH, Clements IP, Fuster V, Elveback LR, Smith HC, Bardsley WT, et al. A platelet-inhibitor drug trial in coronary-artery bypass operations: benefit of perioperative dipyridamole and aspirin therapy on early postoperative veingraft patency. N Engl J Med. 1982;307:73-8.

23. Yusuf S, Zhao F, Mehta SR, Chrolavicius S, Tognoni G, Fox KK, et al. Effects of clopidogrel in addition to aspirin in patients with acute coronary syndromes without ST-segment elevation. N Engl J Med. 2001;345:494-502.

24. Fox KA, Mehta SR, Peters R, Zhao F, Lakkis N, Gersh BJ, et al. Benefits and risks of the combination of clopidogrel and aspirin in patients undergoing surgical revascularization for non-ST-elevation acute coronary syndrome: the
Clopidogrel in Unstable angina to prevent Recurrent ischemic Events (CURE) Trial. Circulation. 2004;110:1202-8.

25. Ebrahimi R, Bakaeen FG, Uberoi A, Ardehali A, Baltz JH, Hattler B, et al. Effect of clopidogrel use post-coronary artery bypass surgery on graft patency. Ann Thorac Surg. 2014;97:15-21.

26. Kulik A, Le May MR, Voisine P, Tardif JC, Delarochelliere R, Naidoo S, et al. Aspirin plus clopidogrel versus aspirin alone after coronary artery bypass grafting: the Clopidogrel After Surgery for Coronary Artery Disease (CASCADE) Trial. Circulation. 2010;122:2680-7.

27. Gao C, Ren C, Li D, Li L. Clopidogrel and aspirin versus clopidogrel alone on graft patency after coronary artery bypass grafting. Ann Thorac Surg. 2009;88: 59-62.

28. Sun JC, Teoh KH, Lamy A, Sheth T, Ellins ML, Jung H, et al. Randomized trial of aspirin and clopidogrel versus aspirin alone for the prevention of coronary artery bypass graft occlusion: the Preoperative Aspirin and Postoperative Antiplatelets in Coronary Artery Bypass Grafting Study. Am Heart J. 2010; 160:1178-84.

29. Gao G, Zheng Z, Pi Y, Lu B, Lu J, Hu S, et al. Aspirin plus clopidogrel therapy increases early venous graft patency after coronary artery bypass surgery a single-center, randomized, controlled trial. J Am Coll Cardiol. 2010;56: 1639-43.

30. Deo SV, Dunlay SM, Shah IK, Altarabsheh SE, Erwin PJ, Boilson BA, et al. Dual anti-platelet therapy after coronary artery bypass grafting: is there any benefit? A systematic review and meta-analysis. J Card Surg. 2013;28: 109-16.

31. Nocerino AG, Achenbach S, Taylor AJ. Meta-analysis of effect of single versus dual antiplatelet therapy on early patency of bypass conduits after coronary artery bypass grafting. Am J Cardiol. 2013;112:1576-9.

32. de Leon N, Jackevicius CA. Use of aspirin and clopidogrel after coronary artery bypass graft surgery. Ann Pharmacother. 2012;46:678-87.

33. Ibrahim K, Tjomsland O, Halvorsen D, Wiseth R, Wahba A, Karevold A, et al. Effect of clopidogrel on midterm graft patency following off-pump coronary revascularization surgery. Heart Surg Forum. 2006;9:E581-856.

34. Mannacio VA, Di Tommasco L, De Amicis V, Antignan A, Vosa C. Aspirin plus clopidogrel for optimal platelet inhibition following off-pump coronary artery bypass surgery: results from the CRYSSA (prevention of Coronary arteRY bypass occlusion After off-pump procedures) randomised study. Heart. 2012; 98:1710-5. 